\title{
The Effect of Lanthanides and Actinides on Blood Coagulation. I. Evidence for and Properties of a New Serum Thromboplastic Factor *
}

\author{
Robert Colman and Benjamin Alexander \\ (From the Yamins Research Laboratory, Beth Israel Hospital, and the Department of Medicine, \\ Harvard Medical School, Boston, Mass.)
}

The anticoagulant action of certain cations, particularly some of the lanthanides, has been known for forty years (2-6), and one of them, neodymium, has been used as an antithrombotic agent $(4,6-11)$. Little is known about the related actinides, such as uranium and thorium. Our interest in thorium derived from studies on the untoward effect of the endotoxin-induced generalized Shwartzman phenomenon on thromboplastin generation (12). Since colloidal thorium dioxide (Thorotrast) can induce the Shwartzman phenomenon $(13,14)$, and since disturbed coagulation and hemorrhagic phenomena have been observed after its administration $(12,14)$, its precise effect on coagulation was explored. Interference with clotting both in vivo and in vitro was so marked and specific as to warrant extension of the study to the related elements, lanthanum, neodymium, cerium, and uranium. As a consequence, a hitherto unrecognized clotting factor has been disclosed that is especially vulnerable to this group of elements and essential for the earliest phase of coagulation, the elaboration of intrinsic blood thromboplastin. The factor has been separated from other known coagulation components, and some of its properties are reported in this communication. An accompanying paper describes an assay method and variations of the factor in health and disease. The effect of this unique group of elements draws attention to the vast and as yet unexplored area relating atomic structure of cations to biologic activity of certain proteins.

\footnotetext{
* Submitted for publication June 4, 1963; accepted December 12, 1963.

Supported by U. S. Public Health Service grant HE-00656.

Presented in part at a Conference of the International Committee on Blood Clotting Factors, Montreux, Switzerland, 1959 (1).
}

\section{Methods}

Thorotrast, 1 containing 24 to $26 \%$ thorium dioxide suspended in a $25 \%$ aqueous solution of dextrin and $0.15 \%$ methyl parasept (preservative); thorium chloride $\left(\mathrm{ThCl}_{4}\right)^{2}$ (analysis: rare earths, $0.03 \% ; \mathrm{Fe}, 0.01 \% ; \mathrm{Ag}$, $0.008 \%$; $\mathrm{Ca}, 0.01 \%$; and $\mathrm{Mg}, 0.01 \%$ ) ; uranium chloride $\left(\mathrm{UCl}_{4}\right) ; 3$ neodymium nitrate $\left(\mathrm{NdCl}_{3} \cdot 6 \mathrm{H}_{2} \mathrm{O}\right) ;^{3}$ cerium chloride $\left(\mathrm{CeCl}_{3} \cdot 7 \mathrm{H}_{2} \mathrm{O}\right) ; 4$ lanthanum chloride $\left(\mathrm{LaCl}_{3}\right.$. $\left.7 \mathrm{H}_{2} \mathrm{O}\right) ;{ }^{4}$ uranyl nitrate $\left.\left[\mathrm{UO}_{2}\left(\mathrm{NO}_{3}\right)_{2} \cdot 6 \mathrm{H}_{2} \mathrm{O}\right)\right] ;{ }^{5}$ barium sulphate $\left(\mathrm{BaSO}_{4}\right) ;^{5}$ and inosithin (inositol phospholipid) ${ }^{6}$ were obtained commercially.

Oxalated plasma. Nine volumes of human or rabbit blood, obtained by venipuncture with ordinary glass syringe and steel needle, was mixed with 1 vol of $0.10 \mathrm{M}$ sodium oxalate. The blood was centrifuged at $1,500 \mathrm{rpm}$ for 10 minutes and the plasma separated. This oxalated plasma was used fresh or after storage at $-12^{\circ} \mathrm{C}$.

Serum was obtained as above, from blood which was allowed to clot in a glass test tube at room temperature. After 2 hours the clot was gently freed, and the tube was centrifuged at $1,500 \mathrm{rpm}$ for 10 minutes. The separated supernatant serum was used fresh, or after storage at $-12^{\circ} \mathrm{C}$.

Platelets. Nine volumes of blood, obtained as above, was added to 1 vol of $2.5 \%$ sodium citrate. The mixture was centrifuged at $800 \mathrm{rpm}$ for 30 minutes, and the separated supernatant plasma was recentrifuged at 4,500 rpm for 30 minutes to sediment the platelets. They were then dispersed and washed 3 times with an equivalent plasma volume of a solution containing $5 \%$ dextrose, $0.2 \%$ sodium acetate, and $0.9 \%$ sodium chloride. The platelets were subsequently suspended to give a platelet count of 250,000 per $\mathrm{mm}^{3}$ of solution.

Platelet-poor plasma. The plasma was separated from the sedimented platelets and aged at $37^{\circ} \mathrm{C}$ to destroy Factor V (proaccelerin).

$\mathrm{BaSO}_{4}$-adsorbed plasma (BaSO 4 plasma). $100 \mathrm{mg}$ BaSO (chemically pure) ${ }^{5}$ was added to each milliliter

1 Testagar \& Co., Detroit, Mich.

2 Amend Drug \& Chemical Co., New York, N. Y.

${ }^{3}$ Lindsay Chemical Division, American Potash and Chemical Corp., West Chicago, Ill.

4 Fisher Scientific Co., Fair Lawn, N. J.

${ }^{5}$ J. T. Baker Chemical Co., Phillipsburg, N. J.

6 Associated Concentrates Co., Woodside, N. Y. 
of fresh ${ }^{7}$ oxalated plasma, the mixture was incubated at room temperature for 15 minutes with frequent stirring, and then centrifuged at $4,500 \mathrm{rpm}$ for 15 minutes, and the supernatant material was separated. The resultant preparations were used fresh, or within 2 weeks of storage, in portions at $-12^{\circ} \mathrm{C}$. Under these conditions, no activity was lost.

Calcium chloride. $0.020,0.025$, and $0.040 \mathrm{M}$ concentrations were used.

Veronal buffered isotonic saline (VBIS), $\mathrm{pH} 7.4$, was made up as follows: $0.100 \mathrm{M} \mathrm{Na}$ Barbital, $200 \mathrm{ml}$; $0.100 \mathrm{~N} \mathrm{HCl}, 144 \mathrm{ml} ; 0.232 \mathrm{~N} \mathrm{NaCl}$ in sufficient quantity to make $1 \mathrm{~L}$.

Veronal buffered oxalated saline (VBOS), $\mathrm{pH} 7.4$, was made up as follows : $0.100 \mathrm{M} \mathrm{Na}$ oxalate, $150 \mathrm{ml}$, and VBIS in sufficient quantity to make $1 \mathrm{~L}$.

Inosithin solution. Inosithin was dispersed (1 $\mathrm{g}$ per $\mathrm{L})$ in VBIS, and the mixture was stored in $0.5-\mathrm{ml}$ samples at $-12^{\circ} \mathrm{C}$.

Human brain thromboplastic solution. This was prepared as described by Tocantins (15).

Factor II (prothrombin) test plasma. ${ }^{8}$ A mixture of 1 vol bovine $\mathrm{BaSO}_{4}$ plasma plus 1 vol human oxalated serum, stored in $1.0-\mathrm{ml}$ portions at $-12^{\circ} \mathrm{C}$ was used. The serum was prepared from freshly shed blood that was promptly mixed with human brain thromboplastin extract (100 ml blood: $3 \mathrm{ml}$ thromboplastin) and allowed to stand for 6 hours; the serum was separated and kept at room temperature overnight, oxalated, and then centrifuged.

Factor VII (proconvertin)-deficient test plasma. Oxalated bovin plasma was filtered through $20 \%$ asbestos filter ${ }^{9}$ and stored in $1.0-\mathrm{ml}$ portions at $-12^{\circ} \mathrm{C}$.

Factor $V$ (accelerator globulin)-deficient test plasma. Human oxalated plasma maintained in liquid state for 48 to 72 hours at $37^{\circ} \mathrm{C}$ until the Quick prothrombin time reached 80 seconds was used. This reagent was then stored in $1.0-\mathrm{ml}$ portions at $-12^{\circ} \mathrm{C}$.

Trypsin. Twice crystallized, salt-free, lyophilized trypsin was obtained commercially. ${ }^{10}$

Cellulose $N, N$-diethylaminoethyl ether (DEAE) ${ }^{11}$ was washed before use with $0.5 \mathrm{M}$ sodium phosphate buffer, $\mathrm{pH} 7.0$, followed by successively more dilute buffers (final, $0.005 \mathrm{M}$ ) at this $\mathrm{pH}$.

Hydrolysed starch.12 $12.4 \mathrm{~g}$ was used per $100 \mathrm{ml}$ buffer, as recommended.

Thromboplastin generation test (TGT). The procedure was essentially that of Biggs and Douglas (17) modified by using Inosithin instead of platelets, and em-

7 This must be fresh; frozen oxalated plasma which is thawed and then adsorbed will not support thromboplastin generation.

${ }^{8}$ Nomenclature of clotting factors is in accordance with that recommended by the International Committee on Blood Clotting Factors (16).

${ }^{9}$ Carlson Laboratories, London, England.

10 Worthington Biochemical Corp., Freeway, N. J.

11 Eastman Organic Chemicals, Rochester, N. Y.

12 Connaught Medical Research Laboratory, Toronto, Ontario, Canada. ploying different volumes. A mixture consisting of $0.50 \mathrm{ml}$ Inosithin solution, $0.10 \mathrm{ml}$ of $\mathrm{BaSO}_{4}$ plasma, $0.05 \mathrm{ml}$ serum, and $0.85 \mathrm{ml}$ VBIS was incubated at $37^{\circ} \mathrm{C}$. Into this mixture $0.5 \mathrm{ml}$ of $0.025 \mathrm{M} \mathrm{CaCl}_{2}$ was blown, and a stop watch was started. At periodic intervals $0.2 \mathrm{ml}$ of this mixture was blown into another test tube containing $0.1 \mathrm{ml}$ platelet-poor plasma kept at $37^{\circ} \mathrm{C}$. The clotting time was recorded and plotted against the incubation time. Each determination was accompanied by a normal control. When Thorotrast, thorium chloride, or rare earth solutions were added in vitro, the results were compared with those concurrently obtained with the untreated serum or $\mathrm{BaSO}_{4}$ plasma to which they were added.

In humans Factor VIII (antihemophilic factor) and Factor $\mathrm{V}$ are present in $\mathrm{BaSO}_{4}$ plasma; Factor IX [plasma thromboplastic component (PTC)] and Factor $\mathrm{X}$ (Stuart factor) are supplied mainly by serum. Substantial amounts of Factors XI [plasma thromboplastic antecedent (PTA)] and XII (Hageman factor) are present in both $\mathrm{BaSO}_{4}$ plasma and $\mathrm{BaSO}_{4}$ serum.

Prothrombin time-one-stage procedure. This test, essentially that of Quick (18), except for the use of human brain thromboplastin (prepared in our laboratory) instead of rabbit (15) reflects the concentrations of Factors I (fibrinogen), II, V, VII, and X. An abnormal test may reflect abnormality in any one, or combination, of these factors.

Determination of Factors $V, V I I$, and II. These were assayed according to the method of Owren and Aas (19), using for each factor the respective test plasma prepared as outlined above. Owren and Aas's procedure for "Factor VII" measures both Factors VII and X; an abnormal test can reflect abnormality of either or both. Determinations of Factors II and V by Owren's procedure are specific for these factors.

Clotting time. This was measured by the orthodox Lee-White procedure, employing three clotting tubes and taking the clotting time of the third tube as the end point.

Platelet count. Platelets were enumerated as described by Ham (20), using Rees and Ecker diluting fluid. In our laboratory normal human blood contains 200,000 to 300,000 per $\mathrm{mm}$ by this method.

Thorium vulnerable factor in serum $(T V F)$ was assayed by a procedure described in the accompanying second paper of this series (21).

Starch gel electrophoresis of a purified serum preparation was performed as previously described (22).

Column chromatography. A slurry of DEAE, prepared as recommended by Peterson and Sober (23), was poured into a chromatography tube $(2 \times 33 \mathrm{~cm})$, filtered through a sintered glass disc of coarse porosity, and then packed with air pressure to give a $25-\mathrm{cm}$ column. Two $\mathrm{L}$ of sodium phosphate buffer $(0.005 \mathrm{M}), \mathrm{pH} 7.0$, was passed through the column under a hydrostatic head of about 3 feet at a flow rate of $40 \mathrm{ml}$ per hour. Four $\mathrm{ml}$ of a purified serum fraction containing a total of $52 \mathrm{mg}$ protein was adsorbed onto the column under gravity, and the top of the column was washed several times with 


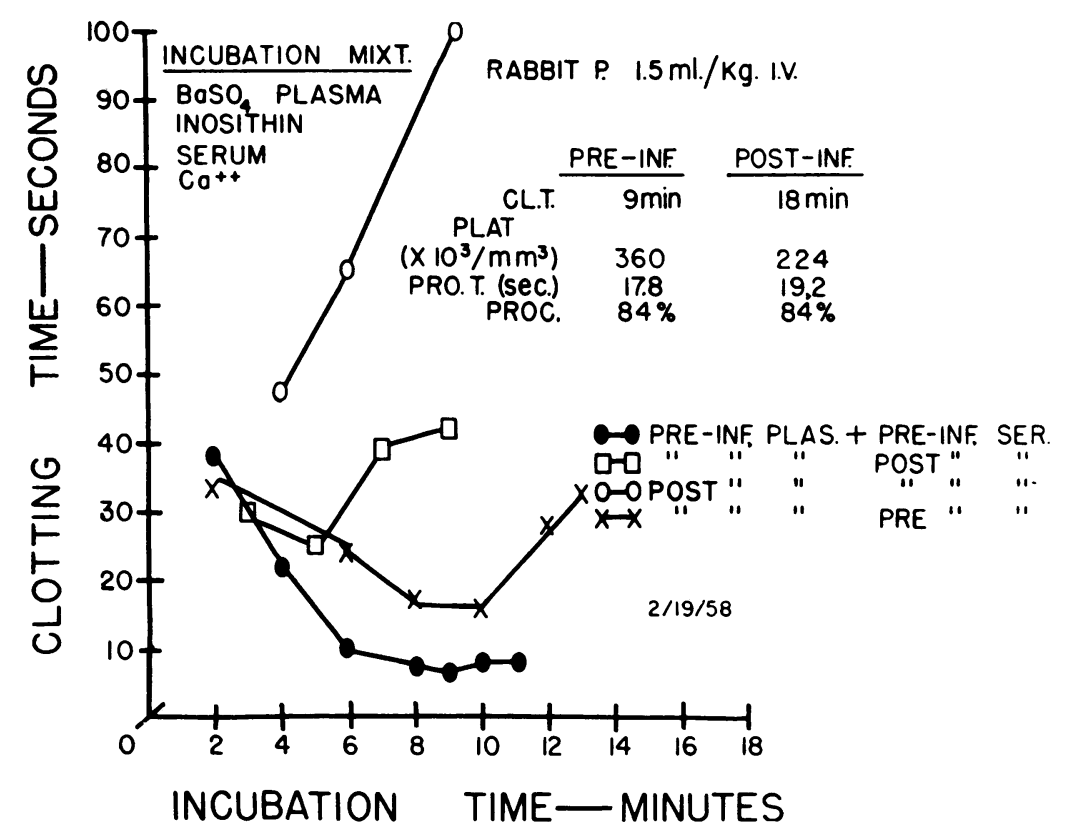

Fig. 1. Thromboplastin generation test (TGT) Before AND AFter thoroTRAST INFUSION to HYBRID, WEANING, albino RabBit. Prothrombin time determined on whole oxalated plasma by Quick procedure with human brain thromboplastin; Factor VII (proconvertin) by Owren method (19). Thorotrast added to a sample of preinfusion blood in vitro ( $1.5 \mathrm{ml}$ per $100 \mathrm{ml}$ blood) produced almost the identical TGT abnormalities.

1-ml portions of the buffer, which was subsequently used as an eluting agent for the first 30 effluent fractions comprising $7 \mathrm{ml}$ each. This was followed by a variable gradient eluant ${ }^{13}$ flowing from a $250-\mathrm{ml}$ mixing chamber initially filled with $0.005 \mathrm{M}$ sodium phosphate buffer, $\mathrm{pH}$ 7.0 , connected to a superiorly suspended reservoir containing $0.4 \mathrm{M}$ sodium acetate and $0.05 \mathrm{M}$ sodium phosphate buffer, $\mathrm{pH}$ 7.0. The first protein peak emerged at the thirty-ninth effluent fraction. At the fiftieth fraction, the reservoir was changed to contain $0.4 \mathrm{M}$ sodium acetate and $0.05 \mathrm{M}$ sodium phosphate, $\mathrm{pH}$ 5.2. The second protein peak emerged at tube 53. The protein concentrations were determined spectrophotometrically by absorption at $280 \mu$. The results were expressed in terms of Kjeldahl nitrogen and recalculated in terms of protein, using the nitrogen to protein ratio found in the purified serum preparation used as the starting material. The specific bilogical activity was expressed as percentage of coagulation factor per milligram protein.

\section{Results}

The infusion into a rabbit of $1.6 \mathrm{ml}$ of Thorotrast per $\mathrm{kg}$ body weight ${ }^{14}$ promptly caused a

13 These conditions for variable elution were found optimal by trial and error.

${ }^{14} \mathrm{An}$ amount which is one-half that generally used as a priming dose $(3.0 \mathrm{ml}$ per $\mathrm{kg}$ ) or as single dose $(4.0 \mathrm{ml}$ per $\mathrm{kg}$ ) to induce the generalized Shwartzman phenomenon (14). marked abnormality in thromboplastin generation (Figure 1). This was associated with an elevation of clotting time and a moderate drop in platelet count. No striking change occurred in the Quick plasma prothrombin time or in Factor VII activity as measured by the Owren procedure. Similar effects on thromboplastin generation could be reproduced in vitro by adding Thorotrast directly to serum or plasma. The magnitude of the defect induced in serum ${ }^{15}$ was directly related to the concentration of Thorotrast; the minimal detectable effect was obtained at a final concentration of $1.7 \%$ (volume of Thorotrast/volume of serum), marked impairment at $3.3 \%$, and almost total inactivation at $6.7 \%$.

Since the effect on human and rabbit blood ap-

15 In these, and all other experiments not aimed at elucidating rates of inactivation, the Thorotrast (or related elements) was added to serum immediately before its use in the TGT. Thus, the serum was only momentarily exposed to the full concentrations indicated and subsequently exposed for the duration of the incubation time of the TGT, at a considerably lower concentration determined by the concentration of serum in the incubation mixture. 
TABLE I

Effect of thorotrast on Factor II (prothrombin), Factor V (accelerator globulin), and Factors VII and X

\begin{tabular}{|c|c|c|c|c|c|c|c|}
\hline \multirow{3}{*}{$\frac{\begin{array}{c}\text { Time after } \\
\text { addition } \\
\text { of Thorotrast }\end{array}}{\text { min }}$} & \multicolumn{7}{|c|}{ Thorotrast in human oxalated plasma, $3.3 \%$} \\
\hline & \multirow{2}{*}{$\begin{array}{c}\begin{array}{c}\text { Quick } \\
\text { prothrombin } \\
\text { time }\end{array} \\
\text { sec }\end{array}$} & \multicolumn{2}{|c|}{ Owren prothrombin } & \multicolumn{2}{|c|}{ Factor V } & \multicolumn{2}{|c|}{$\begin{array}{c}\text { Owren } \\
\text { Factors VII-X }\end{array}$} \\
\hline & & $\sec$ & $\%$ & $\mathrm{sec}$ & $\%$ & $\mathrm{sec}$ & $\%$ \\
\hline 0 & 15.2 & 17.1 & 100 & 27.3 & 100 & 30.1 & 74 \\
\hline 10 & 15.5 & & & 27.8 & 100 & & \\
\hline 15 & & & & 30.0 & 85 & 30.0 & 75 \\
\hline 20 & & 17.0 & 100 & & & & \\
\hline $\begin{array}{l}25 \\
30\end{array}$ & 160 & & & 45 & 33 & 29 & 78 \\
\hline 45 & & & & 45 & 33 & & \\
\hline 60 & 17.0 & 17.0 & 100 & 47 & 30 & 30.0 & 75 \\
\hline
\end{tabular}

peared identical, further study was confined to human material. Inasmuch as both plasma and serum seemed affected, each was studied separately. In plasma, progressive inactivation of Factor $\mathrm{V}$ to one-third its original level occurred

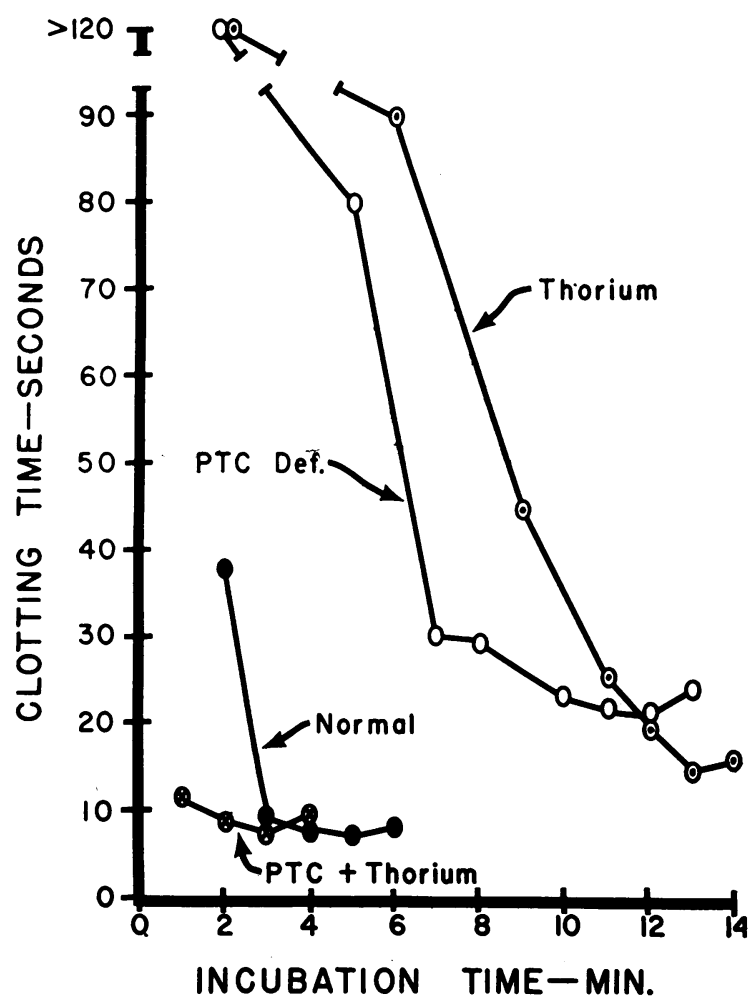

Fig. 2. CORRECTIVE EFFECT OF NORMAL SERUM AND FACTOR IX [PLASMA THROMBOPLASTIC COMPONENT (PTC)]-DEFICIENT SERUM ON THOROTRAST-INDUCED SERUM DEFECT. Incubation mixture contained Inosithin, normal human $\mathrm{BaSO}_{4}$-adsorbed oxalated plasma, and the various sera indicated. Respective sera were mixed $1: 1$, and the combination was then diluted with buffer in the usual manner for the TGT. within 25 minutes after Thorotrast (Table I). This was associated with slight prolongation of the prothrombin time, but the actual concentrations of Factors II and VII (Owren) ${ }^{16}$ remained unchanged.

As will become evident below, a serum component was also adversely affected. To explore the possibility that the plasma and serum entities were identical, experiments were performed in which thorium-treated plasma was admixed with plasma treated with $\mathrm{BaSO}_{4}$ which, as found by prior experience, adsorbs the thorium-vulnerable factor from serum. The data (Table II) indicate that $\mathrm{BaSO}_{4}$ plasma corrects the thorium induced plasma defect. Since, however, $\mathrm{BaSO}_{4}$ adsorbed serum fails to correct the thorium-induced serum abnormality, it is concluded that the serum defect is distinct from the plasma abnormality. Moreover, in experiments not included, the addition or presence of oxalate or citrate in plasma failed to prevent or reverse thorium inactivation, in contrast to serum (see below).

The nature of the serum entity adversely affected was first explored by performing crosscorrection experiments with sera from patients with specific coagulation defects. Factors IX (PTC), X (Stuart), and XI (PTA) were readily excluded, since the defective TGT obtained with sera derived from patients deficient in these specific entities was corrected when admixed with thorium-treated serum, and vice versa (Figures 2, 3, and 4). Moreover, Factor XII could be excluded, since $\mathrm{BaSO}_{4}$ normal plasma, used in the TGT to demonstrate serum defects, contains

\footnotetext{
16 These include both Factors VII and X, as mentioned above in Methods.
} 
TABLE II

Effect of thorium on factor $V^{*}$

\begin{tabular}{|c|c|c|c|c|c|}
\hline \multirow[b]{2}{*}{$\begin{array}{l}\text { Time after } \\
\text { thorium addition }\end{array}$} & \multicolumn{5}{|c|}{ Factor $\mathrm{V}$ activity, $\%$} \\
\hline & $\begin{array}{l}\text { Oxalated } \\
\text { plasma }\end{array}$ & $\begin{array}{l}\mathrm{BaSO}_{4} \\
\text { oxalated } \\
\text { plasma }\end{array}$ & $\begin{array}{l}\text { Thorium } \\
\text { oxalated } \\
\text { plasma }\end{array}$ & $\begin{array}{c}\text { Thorium plasma } \\
\text { plus normal } \\
\text { plasma } \\
1: 1\end{array}$ & $\begin{array}{c}\text { Thorium plasma } \\
\text { plus BaSO4 } \\
\text { plasma } \\
1: 1\end{array}$ \\
\hline \multicolumn{6}{|l|}{$\min$} \\
\hline 0 & 100 & & 100 & & \\
\hline 30 & 100 & & 66 & & \\
\hline 105 & 100 & & 43 & & \\
\hline 195 & & $78 \dagger$ & 30 & 59 & $46 \dagger$ \\
\hline 300 & 51 & $30 \dagger$ & 11 & 42 & $19 \dagger$ \\
\hline
\end{tabular}

* Final $\mathrm{ThCl}_{4}$ concentration was $3 \times 10^{-4} \mathrm{M}$. All plasmas, with or without thorium, were maintained in ice bath for times indicated.

$\dagger$ After 195 minutes, or 300 minutes, 1 part of $\mathrm{BaSO}_{4}$ plasma was mixed with 1 part of thorium-treated plasma and the Factor $V$ activity determined. The observed values ( $46 \%$ and $19 \%$, respectively) agreed quite well with the expected $(54 \%$ and $20.5 \%)$ values.

adequate amounts of this factor (as well as Factors XI). Thus, the thorium-induced serum abnormality could not be related to any of the factors widely accepted as necessary for thromboplastin generation.

Wessler, Reimer, and Freiman (24) have described a serum entity [serum thrombotic accelerator (STA)], which, when infused, induces thrombosis in areas of retarded blood flow. Several samples of thorium-treated serum were still active in the Wessler test system. ${ }^{17}$ This observation, together with the evidence that Factors XII, XI, and IX, which are necessary for STA activity (24), were unaffected by Thorotrast, justifies the conclusion that TVF is not STA.

Because of the importance of surface phenomena in coagulation, it was deemed desirable to

${ }^{17} \mathrm{We}$ are grateful to Dr. S. Reimer for performing these tests.

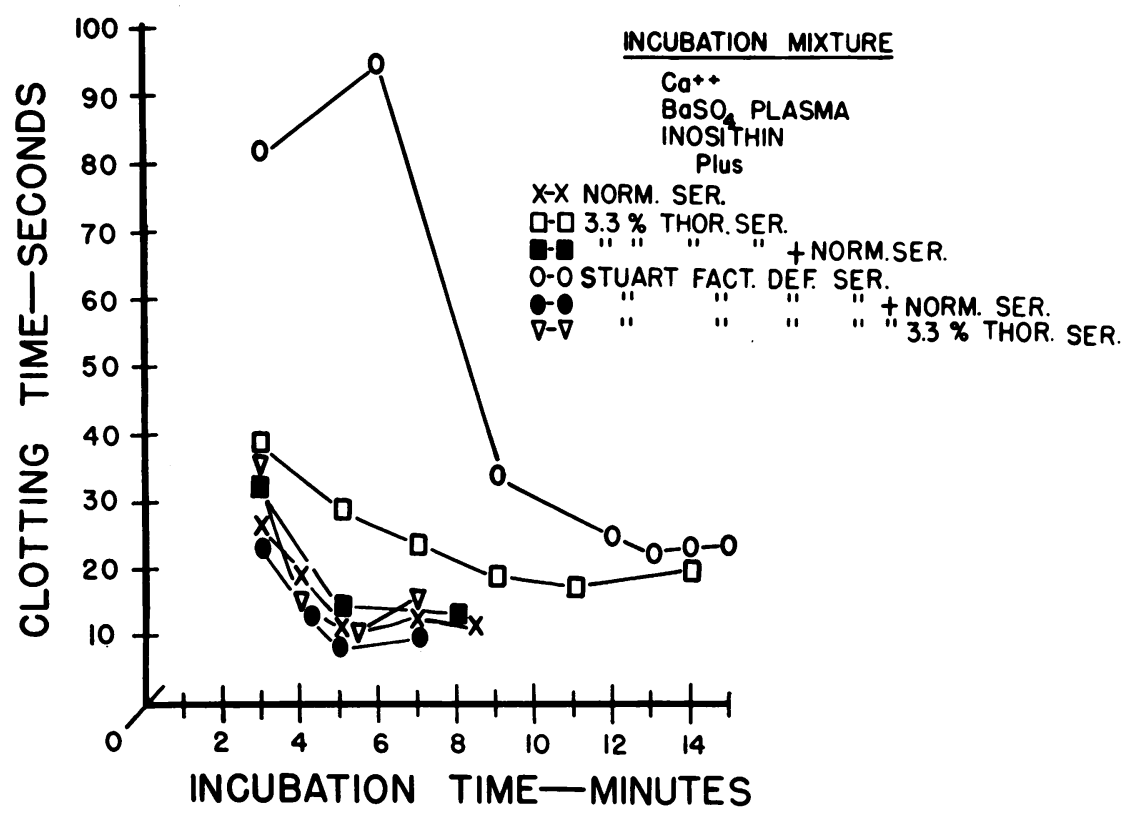

Fig. 3. Mutually corrective effect of admixing Factor X (Stuart)-deficient SERUM WITH THORIUM-TREATED SERUM. Respective sera were mixed $1: 1$, and the combination was then diluted with buffer. 


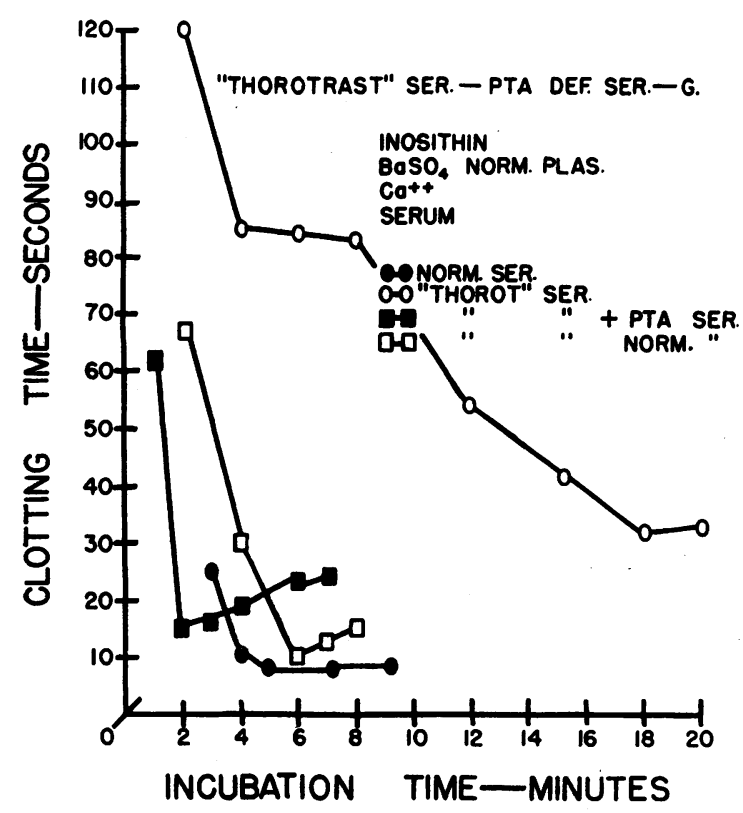

Fig. 4. Corrective effect of Factor XI [Plasma THROMBOPLASTIC ANTECEDENT (PTA)]-DEFICIENT SERUM ON THOROTRAST-INDUCED SERUM DEFECT. The curve reflecting the activity of the PTA serum alone, also markedly abnormal, is omitted for convenience in illustration. determine whether the adverse effect of Thorotrast ${ }^{18}$ was referable to its colloidal nature or to the small amount of thorium existing in cationic form. Thorium chloride-treated serum failed to correct the abnormality in Thorotrasttreated serum, indicating the identity of the defect. On a molar basis the chloride was 50 times more potent than the dioxide. The induced defect was proportional to $\mathrm{ThCl}_{4}$ concentration (Figure 5), and progressive (Figure 6).

Some physicochemical characteristics of the serum TVF were defined. It is adsorbed by $\mathrm{BaSO}_{4}$ (100 mg per ml serum) from which it is elutable by concentrated citrate solutions $(25 \%)$; it is found in the serum proteins precipitated between 50 to $66 \%\left(\mathrm{NH}_{4}\right)_{2} \mathrm{SO}_{4}$ saturation, and it is relatively labile. Serum maintained at 0 to $4^{\circ}$ $\mathrm{C}$ for 21 days fails to correct the thorium induced defect; at $37^{\circ} \mathrm{C}$ the TVF activity decreases markedly within 2 hours, at $50^{\circ} \mathrm{C}$ within 20 minutes (Figure 7). Stability is enhanced by

18 Dextrin, the other component of commercial Thorotrast, was inert.

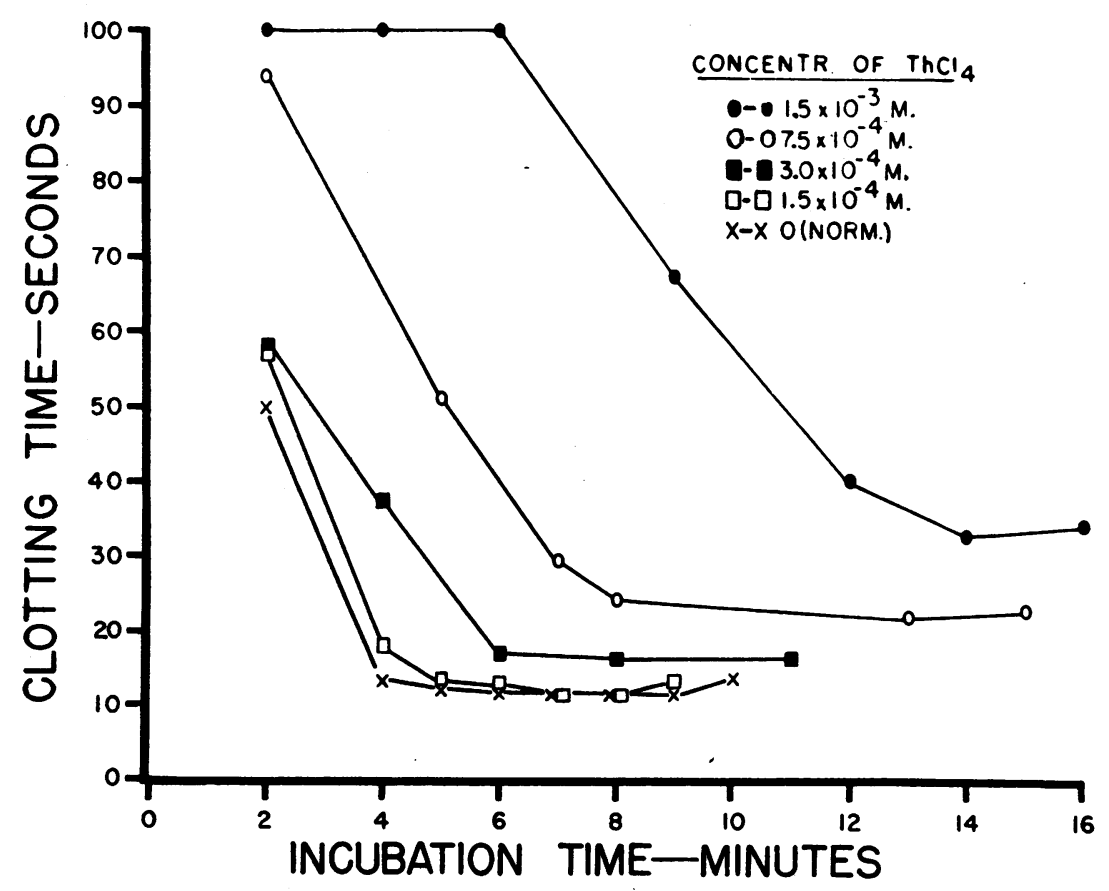

Fig. 5. RELATIONSHip BETWEEN CONCENTRATIONS OF THORIUM CHLORIDE AND SERUM DEFECT IN THE TGT. Molarities indicate final concentrations in serum. The value of $3.0 \times 10^{-4} \mathrm{M}$ would correspond to a final concentration of $3.75 \times 10^{-6}$ in the incubation mixture. 


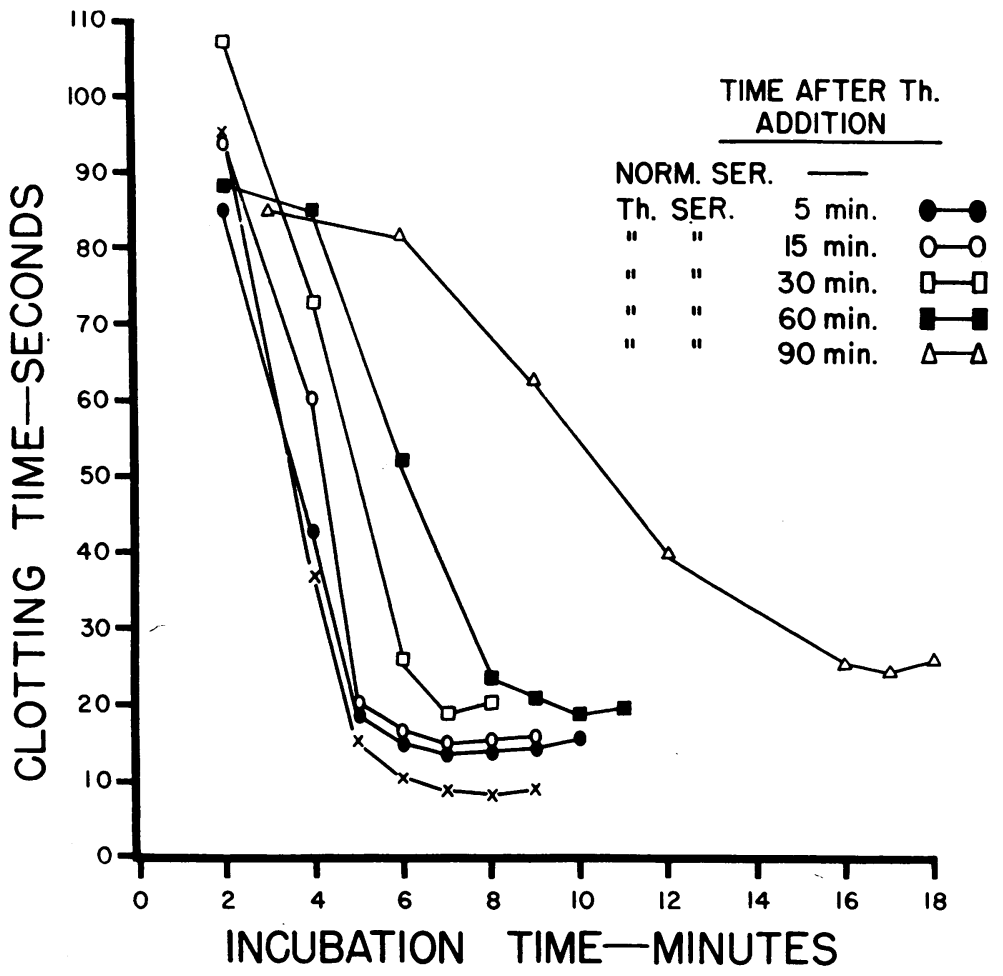

Fig. 6. Progressive inactivation by thorium of SERUM thromboPlastin-Generating potential. $\mathrm{ThCl}_{4}$ was added to normal human serum (final concentration, $3 \times 10^{-4} \mathrm{M}$ ), and TGT was performed at specified intervals thereafter. The TGT incubating mixture contained the usual other components, including Inosithin.

the presence of citrate as used in acid-citratedextrose (ACD) bank blood or in the preparation of citrated plasma (Table III), but not by oxalate.

The thorium-induced serum defect is reversible. The addition of oxalate ${ }^{19}$ to thorium-treated serum (Th, $\left.3 \times 10^{-4} \mathrm{M}\right)$ restored thromboplastin generation to normal (Figure 8), whereas 2.7 $\times 10^{-4}$ is ineffective (not shown), indicating that a critical concentration of oxalate is necessary. Citrate, also, can completely reverse the thoriuminduced serum abnormality. Disodium (ethylenedinitrilo)tetraäcetic acid (EDTA) (final con-

\footnotetext{
19 Question may also be raised as to whether the TGT corrective effects of various specific coagulation defective sera (see above) might be referable to oxalate in the normal $\mathrm{BaSO}_{4}$ plasma component of the TGT incubating mixture. The oxalate concentration under these conditions is far below that required for reversal of the thorium-induced serum defect. Moreover, as evident in Figures 2-4, the thorium defect in serum was demonstrable in the presence of oxalate in normal $\mathrm{BaSO}_{4}$-adsorbed oxalated plasma.
}

centration, $\left.5 \times 10^{-4} \mathrm{M}\right)$ fails to correct the defect, whereas combining EDTA with thorium immediately before its addition to serum prevents inactivation by thorium. EDTA alone in serum $\left(6 \times 10^{-4} \mathrm{M}\right)$ also does not affect the TGT.

Because of the reversibility of the serum de-

TABLE III

Effect of citrate and oxalate on thorium vulnerable factor $(T V F)$ stability*

\begin{tabular}{lc}
\hline \hline \multicolumn{1}{c}{ Anticoagulant } & $\begin{array}{c}\mathrm{TVF} \\
\text { \% of } \\
\text { original }\end{array}$ \\
\hline $\begin{array}{lc}\text { None† } \\
\text { Sodium oxalate, } 1: 5 \text { of } 0.1 \mathrm{M}\end{array}$ & 13 \\
$\begin{array}{l}\text { Sodium citrate, } 1: 5 \text { of } 2.5 \% \\
\text { Acid-citrate-dextrose blood } \\
\text { bank }\end{array}$ & 40 \\
& 61 \\
\hline
\end{tabular}

* Plasma, prepared from blood anticoagulated as above, was recalcified by addition of an equal volume of $0.02 \mathrm{M}$ $\mathrm{CaCl}_{2}$ solution. The serum was separated and incubated at $37^{\circ} \mathrm{C}$ for 4 hours. The original plasma was similarly incubated. then recalcified, and the resultant serum assayed.

$\dagger$ Serum obtained from same blood, obtained without anticoagulant. 


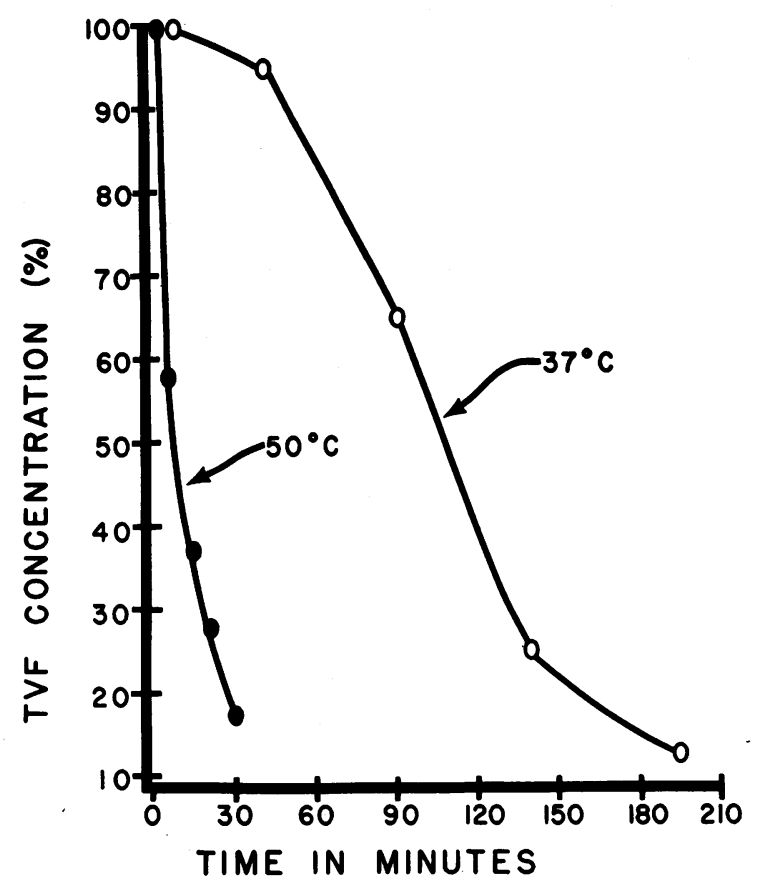

Fig. 7. Thorium vUlNerable Factor (TVF) ACTIVITY OF HUMAN SERUM AT $37^{\circ}$ AND $50^{\circ} \mathrm{C}$. Pool of 14 individual sera.

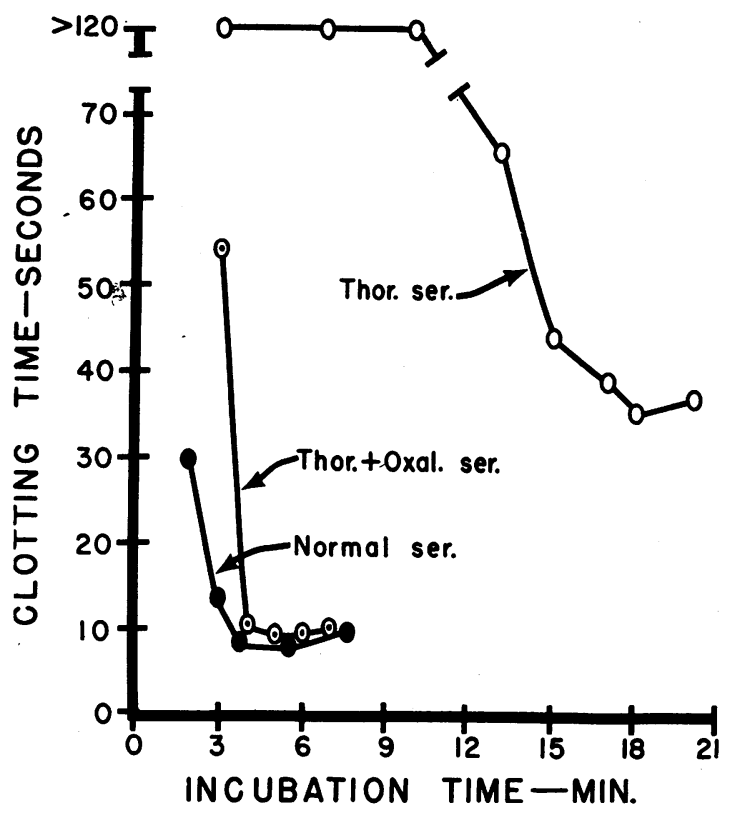

Fig. 8. CORRECTIVE EFFECT OF OXALATE ON THORIUMINDUCED SERUM DEFECT. Sodium oxalate was added to human serum (final concentration, $4 \times 10^{-4} \mathrm{M}$ ) $30 \mathrm{~min}-$ utes after $\mathrm{ThCl}_{4}$ was added (final concentration, $3 \times 10^{-4}$ M).

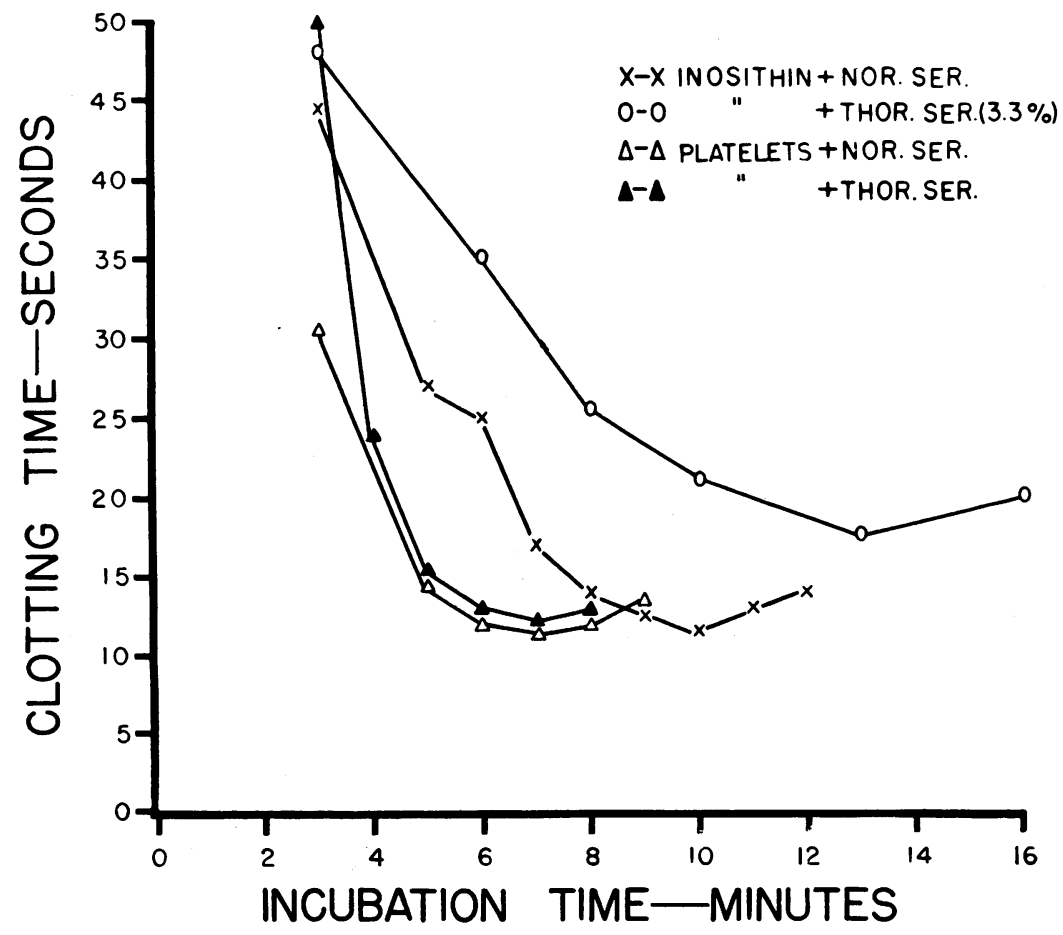

Fig. 9. Ability of Normal platelets to obviate the thorotrast-INdUCEd SERUM DEFECT IN THE TGT. Platelets $(250,000 \mathrm{per} \mathrm{ml}$ of platelet suspension) pretreated with Thorotrast $(0.005 \mathrm{ml}$ per $\mathrm{ml}$ of suspension, an amount exceeding that usually employed to induce the serum defect) supported thromboplastin generation when used with normal serum but not with Thorotrasttreated serum. 
fect by oxalate or citrate, a question arises as to whether the abnormality induced in serum, in contrast to that in plasma (Factor $\mathrm{V}$ inactivation), may be referable to the presence of anticoagulant oxalate $(0.02 \mathrm{M}$ concentration) in the plasma. An experiment was performed ${ }^{20}$ to explore this. $\mathrm{ThCl}_{4}$ was added to normal oxalated plasma (final concentration, $6 \times 10^{-4} \mathrm{M}$ ), the combination was kept at room temperature for 2 hours, then recalcified with an equal volume of $0.02 \mathrm{M} \mathrm{CaCl}_{2}$ solution. Fifteen minutes after coagulation, which required 5 to 7 minutes to occur, the clotted tube was centrifuged for another 10 minutes (room temperature), and the supernatant serum was tested in the TGT side by side with its counterpart derived from recalcified untreated plasma. In contrast to normal thromboplastin generation obtained with the latter, the serum derived from the thorium-treated oxalated plasma was impaired. It thus appears that the TVF, demonstrable in serum, is not only present in plasma but also vulnerable to this element despite the presence of oxalate under the conditions described.

The source of lipid in the TGT appeared important. When platelets replaced Inosithin, the incubation mixture containing thorium-treated serum showed normal generation (Figure 9), suggesting that platelets might be providing TVF. Platelets pretreated with Thorotrast (in amount

${ }^{20}$ By Dr. Araceli Engel.

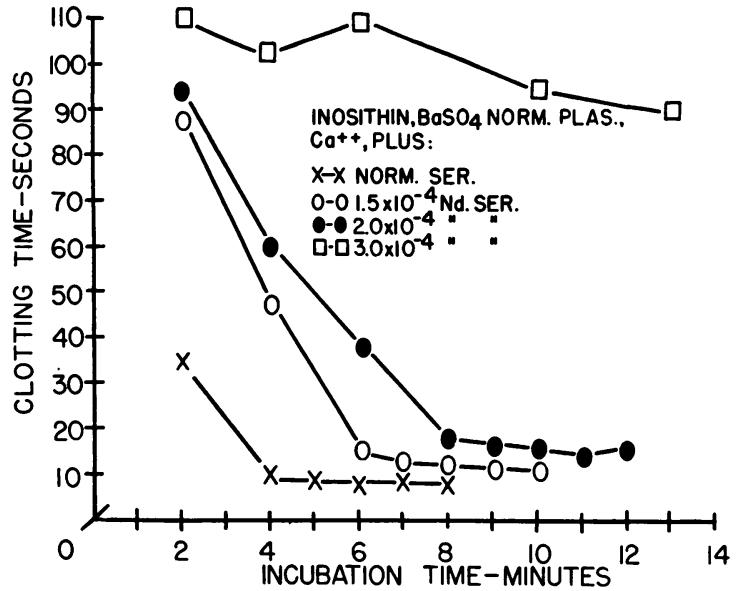

Fig. 10. EFfect of NeOdymium (Nd) on thromboPLASTin-Generating POTENTIAL OF SERUM. Neodymium nitrate added to serum; final concentrations indicated.

exceeding that necessary to produce defective serum) behaved exactly as untreated platelets in a thromboplastin generating mixture containing normal serum. However, the combination of Thorotrast-treated platelets with Thorotrasttreated serum was distinctly abnormal. It thus seems that TVF is present in, or on the surface of, normal platelets.

Because of the known anticoagulant effects of the lanthanides (rare earths), similar studies were performed with neodymium, lanthanum chloride (not shown), and cerium chloride (not shown). Neodymium acted like thorium on both

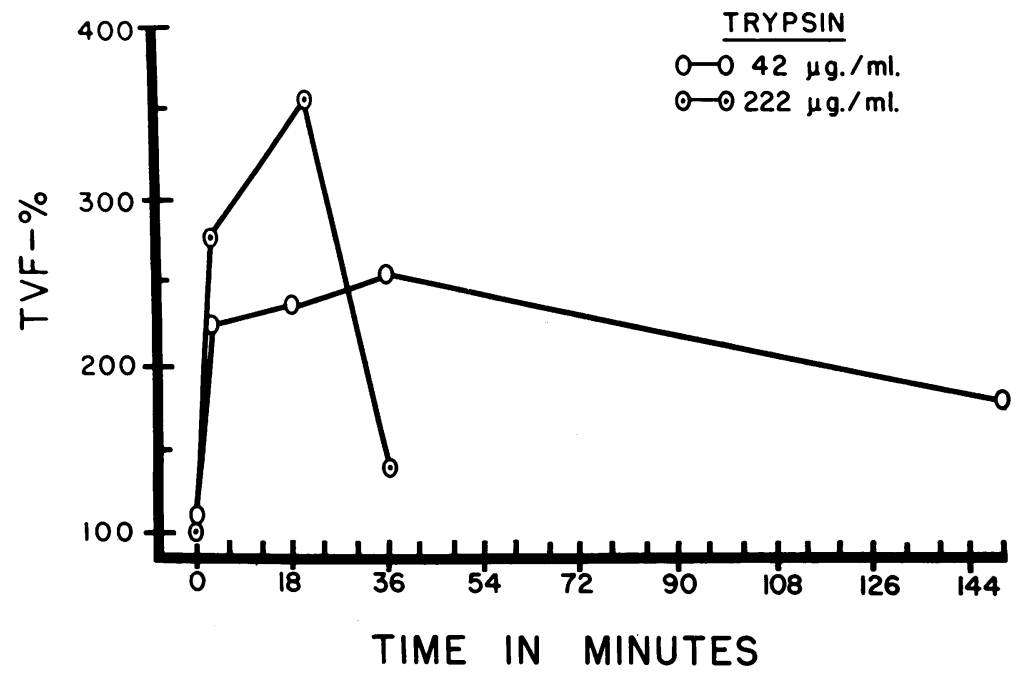

Fig. 11. Activation of thorium vUlNerable factor (TVF) by tRypsin ADDED DIRECTLY TO SERUM. 


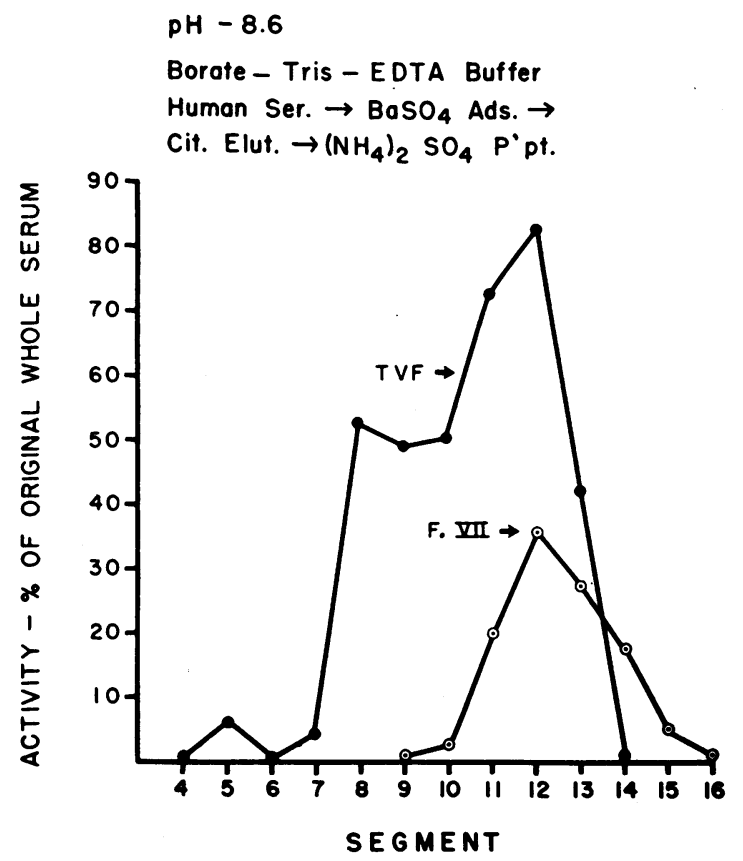

Fig. 12. Starch Gel electrophoretic SEPARATION OF TVF iN PURIFIED FRACTION FROM SERUM. Human serum (Pentex Co., Kankakee, Ill. ) was fractionated according to methods described (22) by adsorption with $\mathrm{BaSO}_{4}$; the adsorbate was eluted with $25 \%$ sodium citrate and dialyzed. The fraction which precipitated at 50 to $66 \%$ ammonium sulfate concentration was dialyzed, and then subjected to electrophoresis on starch gel in borate-TrisEDTA buffer, $\mathrm{pH}$ 8.6. $0.4-$ to $0.6-\mathrm{ml}$ samples were placed in a $7-\mathrm{mm}$ wide slot $7.5 \mathrm{~cm}$ from the end of the starch gel block of $30-\mathrm{cm}$ total length; current was applied for 18 hours at $9^{\circ} \mathrm{C}$ and $200 \mathrm{v}$. The material expressed and eluted from each segment was assayed by procedures described in Methods. The experiment depicted is typical of several similarly performed. Particularly noteworthy are segments 8,9 , and 10 . The material expressed was rich in TVF activity yet devoid of Factor VII activity and Factor X (as measured with Stypven). Factors IX and XI were not determined.

plasma (not shown) and serum (Figure 10) and at approximately the same concentration $(3 \times$ $\left.10^{-4} \mathrm{M}\right)$; admixtures of thorium-treated serum or plasma with their neodymium-treated counterparts were still inactive. All the elements acted the same on serum. Uranium ${ }^{21}$ chloride $\left(\mathrm{UCl}_{4}\right)$ also produced the same serum defect (not shown), but uranyl nitrate $\left[\mathrm{UO}_{2}\left(\mathrm{NO}_{3}\right)_{2}\right]$ was inert in similar concentrations. The unrelated element, zinc $\left(\mathrm{ZnCl}_{2}, 3 \times 10^{-4} \mathrm{M}\right.$ in serum) was also inert ${ }^{22}$ (not shown).

\footnotetext{
21 An actinide as is thorium.

22 Since this paper was first submitted for publication, additional experiments were performed by Dr. Araceli
}

Certain clotting factors (VII and X), existing in plasma or serum as proenzymes, can be markedly activated by the proteases trypsin and papain $(25,26)$. Similarly, when trypsin was added to normal serum, more than threefold enhancement of TVF activity occurred (Figure 11), suggesting that TVF may exist to a considerable extent in serum as a relatively inert zymogen, analogous to Factors VII and X.

Partial separation of TVF from Factor VII was achieved by starch gel electrophoresis (Figure 12). Although some overlapping of activity generally occurred, fractions were obtainable which contained TVF without Factors VII, X, or any other clotting factor activity. Similarly, with DEAE columns a large peak of protein was obtained rich in TVF and uncontaminated by Factors VII, X, or IX (Figure 13). These

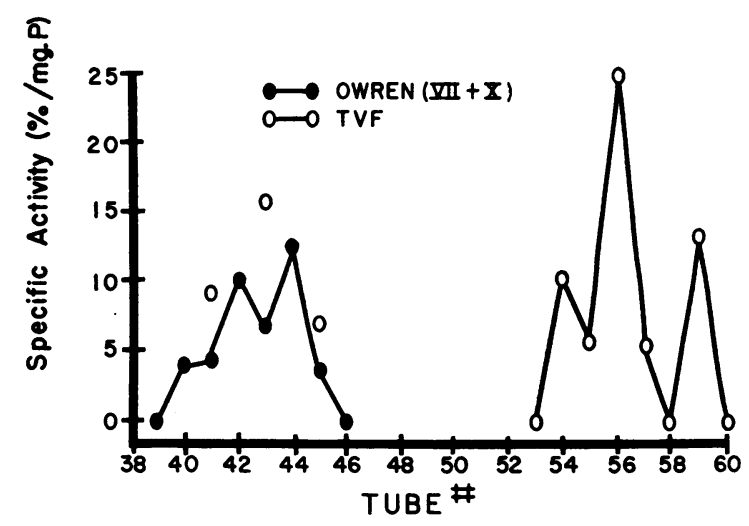

Fig. 13. Chromatographic separation of TVF. Human serum was adsorbed with $\mathrm{BaSO}_{4}$, which was then eluted with $25 \%$ sodium citrate solution. The eluate was then fractionated with ammonium sulfate. The fraction that precipitated at 50 to $66 \%$ saturation was put on a DEAE column, from which material was eluted with a buffer-salt combination providing exponential gradients, ionic strength, and $\mathrm{pH}$ as follows: tubes 1 to 29-buffer no. 1: $0.005 \mathrm{M}$ phosphate buffer, $\mathrm{pH}$ 7.0; tubes 30 to 49 -buffer no. 2: $0.05 \mathrm{M}$ phosphate, $0.40 \mathrm{M}$ sodium chloride, $\mathrm{pH} \mathrm{7.0;} \mathrm{and} \mathrm{tubes} 30$ to 50 -buffer no. 3: $0.05 \mathrm{M}$ phosphate, $0.40 \mathrm{M}$ sodium chloride, $\mathrm{pH}$ 5.2. Noteworthy here, also, are the effluents in tubes 53 to 57 and 59, which contained substantial TVF activity per milligram protein, yet were devoid of Factors VII, X (also determined specifically with Stypven), and IX, as well as other clotting factor activity.

Engel in our laboratory with copper chloride, aluminum chloride, hafnium oxychloride, indium chloride, and gallium chloride, (chosen as valence charge counterparts of the rare earths) in comparable concentrations. All were inert, and the respective sera subjected to them could correct the thorium-induced defect. 
TABLE IV

Properties of thorium vulnerable factor (TVF)

1. Required for thromboplastin generation

2. Serum protein distinct from other serum factors (Factors VII, IX, X, XI, and XII, and serum thrombotic accelerator)

3. Prompt and progressive inactivation by related elements-La, Nd, Ce, Th, and U

4. Reversed by oxalate and citrate, not by EDTA

5. Destroyed at $50^{\circ} \mathrm{C}, 20$ minutes; $37^{\circ} \mathrm{C}, 2$ hours

6. Adsorbed by $\mathrm{BaSO}_{4}$, eluted by citrate

7. Precipitated at 50 to $66 \%\left(\mathrm{NH}_{4}\right)_{2} \mathrm{SO}_{4}$ saturation. Separated by starch gel electrophoresis

8. Activated by trypsin

data also indicate the distinctness of TVF, in harmony with the observations cited above wherein sera from subjects with specific deficiencies in these factors could correct TVFdefective sera and vice versa. Further indications of the distinction are the observations in the accompanying paper of this series (21) showing normal TVF values in the sera of patients with known heredofamilial, induced, or acquired deficiencies of Factors VII, IX, X, and XI.

Some biochemical properties of TVF are summarized in Table IV.

\section{Discussion}

Thorium, either colloidal or as the ionizable chloride, induces a profound coagulation disturbance. In vivo, the over-all defect is reflected in a prolonged clotting time and some reduction in circulating platelets. These abnormalities, in agreement with the results of other workers (2729 ), can explain the hemorrhagic phenomena consequent to thorium administration (14). In vitro, the element rapidly inactivates Factor $\mathrm{V}$ in plasma, and impairs thromboplastin generation. Factors I, II, VII, VIII, IX, X, XI, and XII, all plasma constituents, are unimpaired.

In serum thorium affects an entity, for the time being designated TVF, that is essential for thromboplastin generation and that appears to be distinct from clotting constituents present also in serum-Factors VII, IX, X, XI, and XII. Like the first three, TVF is adsorbed by $\mathrm{BaSO}_{4}$, from which it can be eluted by citrate. It is precipitated at 50 to $66 \%\left(\mathrm{NH}_{4}\right)_{2} \mathrm{SO}_{4}$ saturation, in contrast to Factor XI (25 to 33\%) (30), Factor IX (33 to $50 \%$ ) (30), and Factor XII (25 to $40 \%$ ) (31). Its relative instability also distinguishes it from Factors VII, IX, X, XI, and XII (31-37).

TVF appears also to be distinct from other more recently described and less well defined serum clotting entities. The "prephase accelerator" (PPA) of Duckert, Straub, and Yin (3840 ) is destroyed at $50^{\circ} \mathrm{C}$, but, unlike TVF, it is stable at $4^{\circ} \mathrm{C}$ for many months. Moreover, Factor IX-deficient serum, said to be lacking in PPA also, corrects the thorium-induced defect. Also separable from other coagulation factors by physicochemical means, it is thought to function as an accelerator of the formation of intermediate product I of intrinsic thromboplastin (39). Nevertheless, from the disparate stability characteristic, we must conclude that TVF is not PPA.

Since thorium-treated serum retains the STA activity of Wessler and Reimer (41), TVF must also be distinct from this moiety. This consideration similarly applies to activation product of Henderson and Rapaport (42). This entity, thought to arise from the interaction of Factors XII and XI, has a powerful thrombotic activity when injected intravenously, thus strongly resembling STA.

Less readily distinguishable is TVF from the recently described labile serum fraction of Connor, Warner, and Carter (43), an entity required for normal thromboplastin generation, and with properties remarkably similar to some of those of TVF. Abnormality in this substance was observed in some subjects with unexplained hemorrhagic diathesis, in the newborn, in bishydroxycoumarin (Dicumarol)-treated subjects, and in patients with liver disease. As is reported in the accompanying paper of this series (21), these clinicolaboratory characteristics were also found with TVF. The relationship, if any, between these factors must await further study.

Duckert, Fluckiger, and Koller (44) described an entity deficient in aged serum, which they originally called "Factor X." Except for its relative lability, in most properties this factor resembled what was later described as Stuart Factor (Factor X) (33), which is stable. Whether this substance is identical with TVF remains to be clarified. 
TVF might constitute the activated form of a relatively inert precursor in plasma, e.g., Factor IX or X, rather than a distinct new entity. This possibility is difficult, if not impossible, to accept, since sera from subjects deficient in the activity of these factors (whether due to inadequacy of precursors or activated forms) were able to rectify the TVF-defective sera. Moreover, they had full TVF activity determined by the TVF assay procedure (21). Other distinguishing features are also to be noted: dissociation in response to coumarin therapy as well as in the blood in pregnancy (21). Of additional interest is the observation (not shown) that the addition of Thorotrast to a normal human blood generating mixture at the point of maximal generation (7-minute incubation) was followed by rapid decay of the evolved thromboplastic activity (12), suggesting prompt cessation of further thromboplastin generation.

Thus, the data indicate a new serum factor distinguishable from other factors by its lability, by the ability of the thorium-treated serum to correct the disturbed coagulation associated with all other known defects, and by its separability from other clotting constituents by physicochemical means. Further activation of this factor by trypsin suggests that in plasma the substance may exist in an inert precursor form, as do many other coagulation factors.

Of further interest is the correction of the thorium-induced serum defect by substituting platelets for Inosithin, which is generally used as a source of lipid in the thromboplastin generating mixture. Thrombocytes are known to contain certain plasma and serum coagulation components such as Factor V, in large amounts, and Factors VII, VIII, IX, and I in smaller amounts (45). Conceivably platelet correction of the thorium defect is due to TVF adsorbed on the platelet surface. This interpretation is supported by the fact that neither thorium-treated serum and normal platelets, nor thorium-treated platelets and normal serum, exhibit defective thromboplastin generation, but that when both serum and platelets are exposed to thorium, thromboplastin generation is impaired. The failure of thorium to induce a defect by treatment of platelets alone suggests that there is prior ab- sorption or binding of thorium by platelets, preventing its release into the generating mixture.

The addition to serum of another actinide, uranium, or the related lanthanides, neodymium, cerium, and lanthanum, produced a defect identical to that produced by thorium. These elements have remarkably similar arrangement of their valence electrons, and, as would be expected, they have many chemical properties in common. They do not ionize to any great extent in solution, but are very prone to form co-ordination compounds of great stability because of their high charge (oxidation state) and relatively small ionic radius $(46,47)$. Accordingly, they chelate readily by utilizing the available orbital of the penultimate electron shell. An example is the thorium trichelate of the structure:

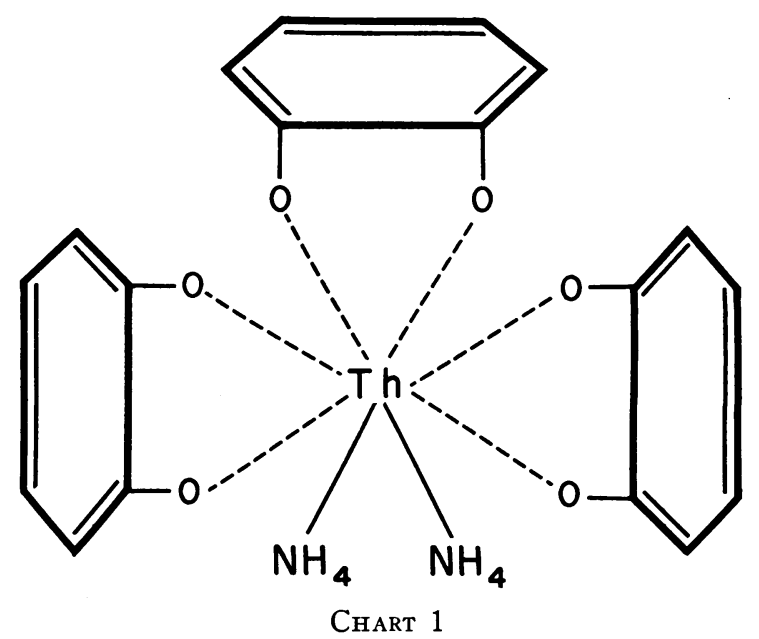

Conceivably, these similar elements could complex with certain biologically functional amino groups of a protein. Indeed, strong complexing ability of rare earth elements with proteins in vivo $(48)$ and in vitro $(49,50)$ has already been demonstrated. The failure of uranyl nitrate $\left[\mathrm{UO}_{2}\left(\mathrm{NO}_{3}\right)_{2}\right]$ to produce a clotting defect might be due to its inability to form such complexes, since four of its available co-ordinate bonds are already linked to oxygen.

Such chelation could promptly and progressively deform a clotting protein, thus altering its biologic behavior. This effect might be reversible if the thorium could somehow be removed from the protein. The failure of extensive dialysis to reverse the defect does indeed indicate binding 
of thorium to some serum component(s). But that this does not result in complete protein denaturation, at least of the specific clotting entities affected, is indicated by the reversibility of the induced defects by oxalate and citrate. These agents are known to form stable complexes with thorium $(46,47)$ of the type:

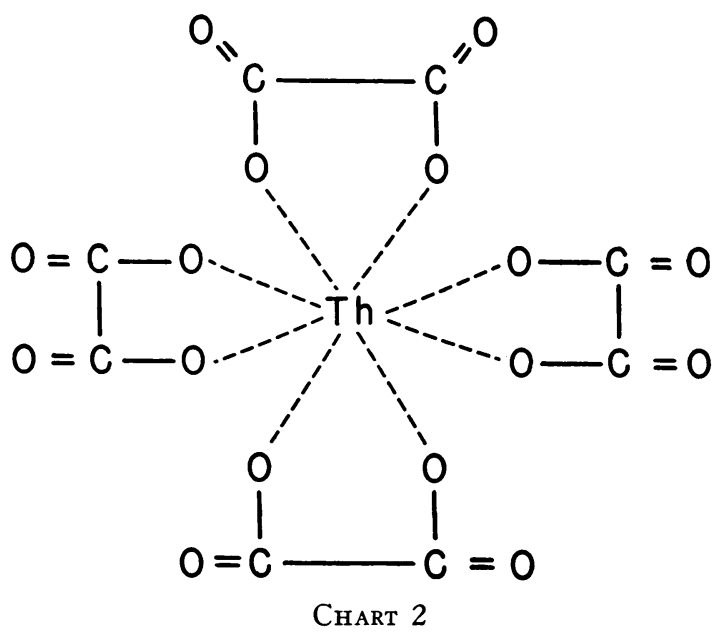

The ability of oxalate and citrate to reverse the defect, presumably by preferential chelation with these elements, argues against a nonspecific complete protein denaturation and supports the concept that these elements combine reversibly with specific sites on the protein essential to its biologic function.

\section{Summary}

1) Thorotrast in vivo promptly induces retarded coagulation and in vitro a profound inability of both plasma and serum to support thromboplastin generation. The same abnormality is induced in serum by thorium chloride and the related elements, neodymium, lanthanum, cerium, and uranium.

2) The plasma defect consists of progressive inactivation of Factor V.

3) The serum defect involves an entity distinct from any hitherto known clotting factor or intermediate. It is adsorbable by $\mathrm{BaSO}_{4}$, elutable by citrate, and it is demonstrable in the protein fraction precipitated at 50 to $60 \%\left(\mathrm{NH}_{4}\right)_{2} \mathrm{SO}_{4}$. The vulnerable factor in serum (TVF) is relatively labile, has been separated from the other coagulation factors by physicochemical means, and can be markedly activated by trypsin.

4) Replacing Inosithin by normal platelets in the thromboplastin generation mixture corrects the thorium-induced defect. In contrast, thorium-treated platelets are inert.

5) Citrate and oxalate completely reverse the thorium-induced defect, but EDTA is ineffective.

6) It is suggested that the lanthanides and actinides produce a defect in serum by forming a reversible complex with a serum protein, which is a hitherto unrecognized clotting factor necessary for thromboplastin generation. The mechanism by which the biologic function of this protein is comprised by this group of elements, structurally similar atomically, appears to be reversible chelation at specific sites on the protein essential for its clotting activity.

\section{References}

1. Alexander, B., and R. Colman. Evidence for a new serum thromboplastin factor. Thrombos. Diathes. haemorrh. (Stuttg.) 1959, 4 (suppl.), 66.

2. Frouin, A., and D. Mercier. Action anticoagulante des sels de terres rares sur sang in vitro. C. $R$. Soc. Biol. (Paris) 1913, 74, 317.

3. Heffter, A., and W. Heubner. Handbuch der Experiment. Pharmak. Berlin, J. Springer, 1930, vol. 3, section 4, p. 2192.

4. Vinke, E. Die Seltenen Erden als Antithrombotica in Proceedings of the First International Conference on Thrombosis and Embolism. Basel, B. Schwabe, 1954, p. 319.

5. Guidi, G. Contributo alla farmacologia delle terre rare: il neodimio. Arch. int. Pharmcodyn. 1930, 37, 305.

6. Dyckerhoff, H., and N. Goossens. Über die Gerinnung des Blutes: Uber Thrombokinase. Biochem. Z. 1938, 299, 437.

7. Vincke, E., and E. Sucker. Das Neodymsalz der 3-Sulfo-Isonikotinsaure als Antithrombotikum. Z Vitamin-, Hormon- u. Fermentforsch. 1949-50, 3, 69.

8. Dyckerhoff, H., W. von Brehm, N. Goossens, and H. Miehler. Uber die Gerinnung des Blutes. II. Biochem. Z. 1936, 288, 271-91.

9. Von Thies, H.-A., and D. Boecker. Klinische Erfahrungen mit einem neuen Anti-thrombotikum aus der Gruppe der Seltenen Erden. Dtsch. med. Wschr. 1953, 78, 222.

10. Hunter, R. B., and W. Walker. Neodymium 3-sulphoisonicotinate and blood coagulation. Brit. med. J. 1956, 2, 1214. 
11. Beller, F. K., and E. Mammen. Der Angriffspunkt der Seltenen Erden Neodym im Gerinnungssytem. Arch. Gynäk. 1956, 187, 319.

12. Alexander, B., A. Kliman, R. Colman, E. Scholtz, and A. deFrancisco. New "Hemophiloid" Defects : Some Clinico-Laboratory and Experimental Abnormalities in Thromboplastin Generation. Hemophilia and Other Hemorrhagic States, K. Brinkhous, Ed. Chapel Hill, University of North Carolina Press, 1959.

13. Good, R. A., and L. Thomas. Studies on the generalized Shwartzman reaction. II. The production of bilateral cortical necrosis of the kidneys by a single injection of bacterial toxin in rabbits previously treated with Thorotrast or trypan blue. J. exp. Med. 1952, 96, 625.

14. Fine, J., H. Rutenberg, and F. B. Schweinberg. The role of the reticulo-endothelial system in hemorrhagic shock. J. exp. Med. 1959, 110, 547.

15. Tocantins, L. M., Ed. Coagulation of Blood: Methods of Study. New York, Grune \& Stratton, 1955.

16. Progress in Coagulation. Thrombos. Diathes. haemorrh. (Stuttg.) 1962, 7 (suppl.), 379.

17. Biggs, R., and A. S. Douglas. Thromboplastin generation test. J. clin. Path. 1953, 6, 23.

18. Quick, A. J. The clinical application of the hippuric acid and prothrombin tests. Amer. J. clin. Path. 1940, 10, 222.

19. Owren, P. A., and K. Aas. The control of Dicumarol therapy and the quantitative determination of prothrombin and proconvertin. Scand. J. clin. Lab. Invest. 1951, 3, 201.

20. Ham, T. H. A Syllabus of Laboratory Examination in Clinical Diagnosis. Cambridge, Mass., Harvard University Press, 1957.

21. Alexander, B., and R. Colman. The effect of lanthanides and actinides on blood coagulation. II. Assay of a new serum thromboplastic factor vulnerable to these elements and its variations in health and disease. J. clin. Invest. 1964, 43, 720.

22. Tishkoff, G. H., L. Pechet, and B. Alexander. Some biochemical and electrophoretic studies on purified prothrombin, Factor VII (proconvertin) and Factor X (Stuart). Blood 1960, 15, 778.

23. Peterson, E. A., and H. A. Sober. Chromatography of proteins. I. Cellulose ion-exchange adsorbents. J. Amer. chem. Soc. 1956, 78, 751.

24. Wessler, S., S. M. Reimer, and D. G. Freiman. Thrombosis inducing factors in serum. Thrombos. Diathes. haemorrh. (Stuttg.) 1959, 4 (suppl.), 201.

25. Alexander, B., and L. Pechet. Proteolytic and physiologic activation of some clotting components: pathologic significance. Proc. VIII Congress European Soc. Haemat. 1961, 2, 404.

26. Alexander, B., L. Pechet, and A. Kliman. Proteolysis, and coagulation; significance in thrombolytic therapy. Circulation 1962, 26, 596.
27. Reeves, D. L., and R. M. Stuck. Clinical and experimental results with thorotrast. Medicine (Baltimore) 1938, 17, 37-73.

28. Greenbaum, F. R.; and C. E. Aye. Pharmacological behavior of sodium thorium tartrate and its roentgen diagnostic value. Amer. J. Roentgenol. 1941, 45, 265.

29. Bodi, T., R. R. Holburn, J. Geldner, R. T. Carol, and L. M. Tocantins. Studies of the effect of thorotrast on blood coagulation. Thrombos. Diathes. haemorrh. (Stuttg.) 1959, 3, 357.

30. Rosenthal, R. L., O. H. Dreskin, and N. Rosenthal. Plasma thromboplastic antecedent (PTA) deficiency: clinical coagulation, therapeutic and hereditary aspects of a new hemophilia-like disease. Blood 1955, 10, 120.

31. Ratnoff, O. D., and J. E. Colopy. Familial hemorrhagic trait associated with a deficiency of clotpromoting fraction of plasma. J. clin. Invest. 1955, 34, 602.

32. Geratz, J. D., and J. B. Graham. Plasma thromboplastin component (Christmas Factor, Factor IX) levels in stored human blood and plasma. Thrombos. Diathes. haemorrh. (Stuttg.) 1960, 4, 376388.

33. Hougie, C., E. M. Barrow, and J. B. Graham. Stuart clotting defect I. Segregation of an hereditary hemorrhagic state from the heterogeneous group heretofore called "stable factor" (SPCA, proconvertin, Factor VII) deficiency. J. clin. Invest. 1957, 36, 485.

34. Rosenthal, R. L. Properties of plasma thromboplastin antecedent (PTA) in relation to blood coagulation. J. Lab. clin. Med. 1955, 45, 123.

35. Frick, P. G., and P. S. Hagen. Severe coagulation defect without hemorrhagic symptoms caused by a deficiency of the fifth plasma thromboplastin precursor. J. Lab clin. Med. 1956, 47, 592.

36. Aggeler, P. M., S. G. White, M. B. Glendening, E. W. Page, T. B. Leake, and G. Bates. Plasma thromboplastin component (PTC) deficiency: a new disease resembling hemophilia. Proc. Soc. exp. Biol. (N. Y.) 1952, 79, 692.

37. Spaet, T. H., and M. Kropatkin. Factor X phenomenon. J. appl. Physiol. 1959, 14, 581.

38. Duckert, F. The prephase accelerator. Present status. Thromos. Diathes. haemorrh. (Stuttg.) 1961, 6, 254.

39. Straub, W. Separation of coagulation factors by means of starch gel electrophoresis. Thrombos. Diathes. haemorrh. (Stuttg.) 1960, 4, 451.

40. Duckert, F., E. T. Yin, and W. Straub. Separation and purification of the blood-clotting factors by means of chromatography and electrophoretic methods. Preparative methods. Protides of the biological fluids. Proc. 8th Colloquium, Bruges, 1960. Amsterdam, Elsevier, 1961, p. 41. 
41. Wessler, S., and S. M. Reimer. The role of human coagulation factors in serum-induced thrombosis. J. clin. Invest. 1960, 39, 262.

42. Henderson, E. S., and S. I. Rapaport. The thrombotic activity of activation product. J. clin. Invest. 1962, 41, 235.

43. Connor, W. E., E. D. Warner, and J. R. Carter. A labile serum factor clotting defect: its demonstration by the thromboplastin generation test and its clinical significance. J. clin. Invest. 1961, 40, 13.

44. Duckert, F., P. Fluckiger, and F. Koller. Le rôle du Facteur $\mathrm{X}$ dans la formation de la thromboplastine sanguine. Rev. Hémat. 1954, 9, 489.
45. Adelson, E., J. J. Rheingold, and W. H. Crosby. The platelet as a sponge: a review. Blood 1961, 17, 767.

46. Sidgwick, N. V. The Chemical Elements and Their Compounds. Oxford, Clarendon Press, vol. 1, 1950.

47. Bailer, J. C., Jr. The Chemistry of Coordination Compounds. New York, Reinhold, 1956.

48. Snyder, F., E. A. Cress, and G. C. Kyker. Rare earth fatty liver. Nature (Lond.) $1960,185,480$ 81.

49. Snyder, F. Personal communication, 1961.

50. Rosoff, B., F. Stand, and H. Spencer. Rare earth binding to serum proteins and nucleic acid. Fed. Proc. 1962, 21, 421. 